Н. В. Гурець, стариий викладач

кафедри екології та природоохоронних технологій e-mail: natalya.gurets@nuos.edu.ua

Національний університет кораблебудування імені адмірала Макарова, пр-т. Героїв України, 9, м. Миколаїв, Україна

\title{
УПРАВЛІННЯ ПРОЕКТОМ ВПРОВАДЖЕННЯ СИСТЕМИ ЕКОЛОГІЧНОГО МЕНЕДЖМЕНТУ У МУНІЦИПАЛЬНИХ УТВОРЕННЯХ
}

На сучасному етапі розвитку суспільства найбільш гострими проблемами муніципальних утворень є екологічні, пов'язані з надмірною конщентрачією на обмежених територіях населення, транспорту і промислових підприємств. Одним із ефективних шляхів вирішення вищезазначених проблем є реалізація місиевими адміністраціями проектів впровадження системи екологічного менеджменту, які дозволяють зменшувати негативний вплив на довкілля при одночасній економії фінансових та матеріальних ресурсів. У статті розглянуто сутність та класифікачійні характеристики проекту впровадження системи екологічного менеджменту; визначено мету, продукт та основні ризики при його реалізації, виокремлено особливості управління проектом саме у муніципальних утвореннях. Проведений аналіз доводить необхідність застосування методів превентивного управління при підготовичі та реалізації проекту впровадження системи екологічного менеджменту, обов'язкового включення до проекту методів управління витратали ресурсів і енергї та врахування інтересів заиікавлених сторін проекту на всіх стадіях життєвого ииклу.

Ключові слова: система екологічного менеджменту, проект впровадження системи екологічного менеджменту, організаційний проект, зацікавлені сторони проекту.

Вступ. Різке погіршення стану навколишнього середовища на території муніципальних утворень внаслідок збільшення виробничих потужностей нових виробництв та загострення їх впливу на природу; зростання чисельності населення та збільшення обсягів утворення небезпечних відходів, збільшення чисельності автотранспорту викликає необхідність впровадження системи екологічного менеджменту (CEM) в управління муніципальним утворенням.

Впровадження екологічного менеджменту у муніципальних утвореннях здійснюється шляхом розробки та реалізації проектів СЕМ. Тому дослідження особливостей управління проектами впровадження екологічного менеджменту у муніципальних утвореннях $\epsilon$ доволі актуальним.

Аналіз останніх досліджень. Дослідженню процесу розробки, впровадження та функціонування системи екологічного менеджменту присвячені праці таких вчених, як О. В. Астафьєва [1], Ю.В.Бабина, Г.В.Белов, І. І. Дуднікова, Л. Н. Бельдеєва, А. Л. Бобровський, Є. А. Варфоломєєва, С. Є. Дерягина [1], Л. Ф. Кожушко, Л. А. Кормина, Л. В. Купреєва, С. І. Лебедевич, Ю. М. Мель- ник, В. О. Мартиненко [3], І. В. Ремешевська, М. 3. Свиткин, Н. В. Селіванова, Т. А. Трифонова, Т. Б. Харченко та ін. Так, в роботах $[1,3]$ обгрунтовано доцільність та переваги впровадження СЕМ у структурі муніципального управління. Проте в більшості наукових праць розглядається питання функціонування i впровадження екологічного менеджменту переважно на промислових підприємствах.

Питанням управління проектами в екологічній сфері присвячені роботи таких українських вчених, як Н. О. Гавадзин [2], М. М. Олексієнко [4], Ю. А. Петренко, Ю. П. Рак, В. А. Рач, О. В. Росошанська, С. В. Руденко [5], Ю. Н. Харитонов, В. О. Хрутьба [8] та ін. Серед зарубіжних вчених у цьому напрямку проводили дослідження B. Ackles, M. Chaerul, J. Nouri, N. Panya [9], M. Tanaka, S. Toutounchian, D. Shirley, A. J. G. Silvius, M. S. Reed [10], C. P. Vorratnchaiphan, F. V. Malmborg.

В роботі [2] запропоновано технології управління екологічними проектами, які можуть попереджувати, ефективно регулювати чи вирішувати еколого-економічні проблеми. Дослідженню системності екологічних проектів та застосуванню проактивного під- 
ходу до побудови системи управління екологічним проектом присвячена робота [4]. У праці [5] проводиться оцінювання результатів екологічних проектів. Висвітленню проблеми участі зацікавлених сторін у створенні і реалізації проектів екологічного менеджменту присвячено роботи [6], [10]. Креативну модель проекту впровадження системи екологічного менеджменту транспортного підприємства представлено у роботі [8]. Таким чином, проведений аналіз показує, що дослідження управління проектом впровадження СЕМ на рівні муніципального утворення практично відсутні.

Метою статті $\epsilon$ визначення мети, завдань та основних класифікаційних характеристик проекту впровадження СЕМ, висвітлення основних зацікавлених сторін та особливостей управління таким проектом.

Викладення основного матеріалу. Останнім часом у зв'язку зі зростанням законодавчих вимог та підвищенням зацікавленості громадськості у питаннях збереження довкілля все більшу роль у процесі управління муніципальними утвореннями відіграють проекти екологічного спрямування. Серед них важливе місце займають проекти впровадження СЕМ.

Процес створення і впровадження СЕМ в організації згідно зі стандартом ISO 14000 [7] включає розробку екологічної політики, 3 урахуванням інтересів усіх зацікавлених сторін; оцінювання існуючої ситуації; встановлення характеристик діяльності, що підляга- ють поліпшенню; розробку екологічної програми, що деталізує шлях і стадії вирішення поставлених завдань; практичне втілення запланованої діяльності; проведення моніторингу, коригувальних дій, аналізу і аудиту; проведення аналізу з боку керівництва 3 метою забезпечення постійного вдосконалення СЕМ.

В результаті впровадження проектів СЕМ знижується рівень забруднення викидами та скидами шкідливих речовин; спостерігається економія енергії і природних ресурсів, а відповідно і коштів організації; поліпшується стан навколишнього середовища; посилюється «зелений» імідж організації; покращуються взаємовідносини між різними групами місцевих мешканців.

Процес реалізації проекту впровадження СЕМ передбачає пошук відповідності між ключовими елементами організації, такими як структура, персонал, завдання, система рішень і заохочень, культура та іiі стратегія у напрямку досягнення успіху, тому за характером та сферою діяльності такий проект належить до організаційного типу. Інші класифікаційні характеристику проекту надані в табл. 1 .

Продуктом проекту виступає діюча в організації СЕМ або Сертифікат системи екологічного менеджменту, який підтверджує їі наявність. Крім того, важливо забезпечити реалізацію принципу постійного вдосконалення протягом всього життєвого циклу проекту.

Класифікаційні характеристики проекту впровадження СЕМ

Таблиця 1

\begin{tabular}{|c|c|c|c|}
\hline $\begin{array}{c}\text { Критерій для } \\
\text { класифікації }\end{array}$ & $\begin{array}{c}\text { Класифікаційна } \\
\text { ознака }\end{array}$ & $\begin{array}{c}\text { Належність проек- } \\
\text { ту впровадження } \\
\text { СЕМ до категорії }\end{array}$ & Підстави вибору категорії \\
\hline $\begin{array}{c}\text { Клас } \\
\text { проекту }\end{array}$ & $\begin{array}{c}\text { За складом та } \\
\text { структурою } \\
\text { проекту }\end{array}$ & Мультипроект & $\begin{array}{c}\text { Комплексний проект організації, який } \\
\text { складаєтья з декількох монопроектів } \\
\text { впровадження СЕМ у їі підрозділах }\end{array}$ \\
\hline Тип проекту & $\begin{array}{c}\text { За основними } \\
\text { сферами } \\
\text { діяльності, } \\
\text { в яких } \\
\text { здійснюється } \\
\text { проект }\end{array}$ & $\begin{array}{c}\text { В загальну систему управління інтег- } \\
\text { рується СЕМ, яка включає організа- } \\
\text { ційну структуру, діяльність із плану- } \\
\text { вання, обов’язки, відповідальність, } \\
\text { досвід, методи, методики, процеси і } \\
\text { ресурси для розробки, здійснення й } \\
\text { аналізу екологічної політики }\end{array}$ \\
\hline Вид проекту & $\begin{array}{c}\text { За характером } \\
\text { цільового } \\
\text { завдання }\end{array}$ & Реорганізаційний & $\begin{array}{c}\text { Спостерігається реорганізація існую- } \\
\text { чої системи управління }\end{array}$ \\
\hline
\end{tabular}




\begin{tabular}{|c|c|c|c|}
\hline $\begin{array}{l}\text { Тривалість } \\
\text { проекту }\end{array}$ & $\begin{array}{c}\text { За тривалістю } \\
\text { періоду реалізації } \\
\text { проекту }\end{array}$ & Короткостроковий & Реалізується протягом 1-2 років \\
\hline $\begin{array}{c}\text { Масштаб } \\
\text { проекту }\end{array}$ & За обсягом робіт & Середній & \multirow{2}{*}{$\begin{array}{c}\text { Супроводжується реалізацією новіт- } \\
\text { ніх завдань у сфері управління до- } \\
\text { вкіллям, потребує застосування су- } \\
\text { часних знань, високого професійного } \\
\text { рівня управлінської команди та рете- } \\
\text { льної підготовки всіх його складових. }\end{array}$} \\
\hline $\begin{array}{l}\text { Складність } \\
\text { проекту }\end{array}$ & $\begin{array}{c}\text { За ступенем } \\
\text { складності } \\
\text { реалізації проекту }\end{array}$ & $\begin{array}{l}\text { Організаційно } \\
\text { складний проект }\end{array}$ & \\
\hline $\begin{array}{c}\text { Характер } \\
\text { змін } \\
\text { проекту }\end{array}$ & $\begin{array}{c}\text { За характером } \\
\text { змін }\end{array}$ & Стратегічний & $\begin{array}{c}\text { Впливає на концептуальні позиції } \\
\text { організації }\end{array}$ \\
\hline
\end{tabular}

Проекти впровадження СЕМ в органах місцевого самоврядування та на комунальних підприємствах, як правило, реалізуються в умовах наявності незначних фінансових ресурсів, а членами команди проекту стають співробітники відповідної організації, які суміщають роботу по проекту зі своїми основними функціональними обов'язками, тому типовими обмеженнями таких проектів є обмеження бюджету, кількості людських ресурсів та відповідно обсягу роботи, який може виконати команда.
Важливу роль для успішної реалізації проекту впровадження СЕМ у муніципальному утворенні відіграє аналіз та ідентифікація зацікавлених сторін, що дозволяє досягти задоволення їхніх потреб, особливо, якщо в проекті проявляються різні групи зацікавлених сторін 3 різними, а іноді навіть протилежними, інтересами, що створює певні перешкоди в реалізації проекту $[6,10]$. Зацікавлені сторони проекту зображено на рис. 1.

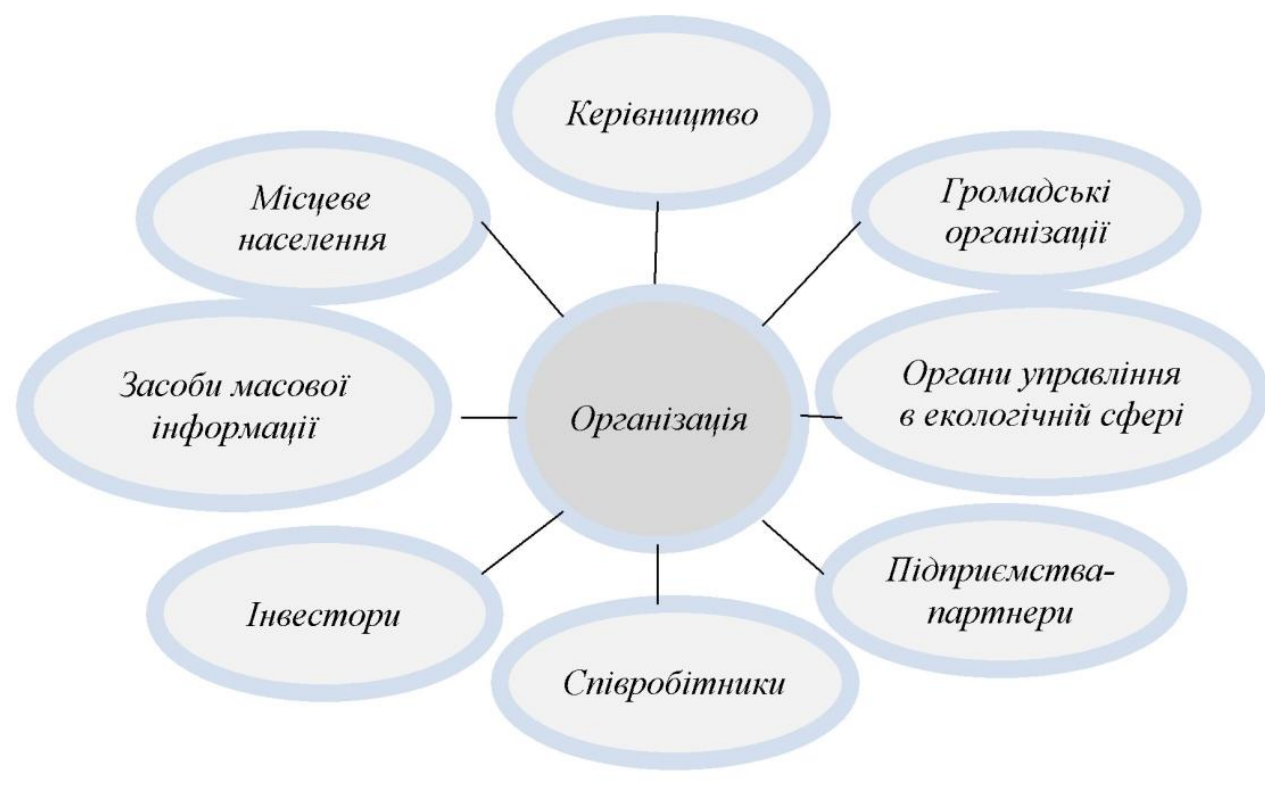

Рис. 1. Зацікавлені сторони проекту впровадження СЕМ

На рівні муніципального утворення в проекті впровадження СЕМ керівництво місцевої адміністрації або комунального підприємства виступає як інвестор, замовник та користувач проекту одночасно. В ролі інвестора керівництво відповідних організацій виділяе ресурси для проекту і впливає на формування проектної команди, в ролі замовника - отримує результат реалізації проекту, тобто діючу CEM, яку має можливість використовувати як 
користувач, отримуючи всі переваги від ii впровадження. Якщо керівництво вищезазначених організацій для реалізації проекту бере участь у грантових програмах або отримує позику у відповідних установах, то організації, що надають гранти або позики, також виступають в ролі інвесторів.

Однією з особливостей реалізації проекту впровадження СЕМ на рівні муніципального утворення $\epsilon$ також той факт, що користувачами також виступають місцеві спільноти, тобто групи людей, які проживають на одній території. До них, в свою чергу, можна віднести цільові групи: місцеві спільноти як такі; органи державного управління в екологічній сфері; громадські організації, які формують суспільну думку.

Місцеві спільноти представлені населенням, що проживає на території муніципального утворення. До органів державного управління в екологічній сфері можна віднести управління екології та природних ресурсів облдержадміністрації, головні управління Державної служби надзвичайних ситуацій України в областях, обласні управління Державної служби з питань безпечності харчових продуктів та захисту споживачів.

Громадські організації зазвичай представлені чисельними групами соціально активних громадян, які мають на меті певні політичні, соціальні або інші цілі. До них належать місцеві осередки політичних партій та різноманітні спілки громадян (наприклад організації типу «зелених»). Взаємодія з громадськими організаціями реалізується шляхом проведення опитувань, круглих столів або конференцій за визначеною проблематикою.

Керівником (менеджером) проекту впровадження CEM, який відповідає за управління проектом та його результати, може бути співробітник місцевої адміністрації або комунального підприємства, а також депутат місцевої ради, наприклад голова постійної депутатської комісії з екологічних питань. Під його керівництвом формується команда проекту, до якої входять фахівці відповідних організацій, депутати місцевих рад, члени виконкомів, представники громадських організацій, наукових установ, які працюють над реалізацією проекту і представляють інтереси різних зацікавлених сторін проекту.

Серед інших зацікавлених сторін проекту можна виділити підприємства-партнери, які виконують різноманітні види робіт з прое- ктування, будівництва, експлуатації обладнання та матеріально-технічного забезпечення проекту, а також засоби масової інформації.

Створення i впровадження системи екологічного менеджменту всередині організації приводить до змін організаційного характеру, тому до зацікавлених сторін також слід відносити співробітників місцевих адміністрацій або комунальних підприємств.

Основними особливостями проектів впровадження СЕМ $є$ те, що прийняття стратегічних рішень визначається відповідно до стратегії сталого розвитку, за якої досягається задоволення життєвих потреб нинішнього покоління без позбавлення майбутніх поколінь таких можливостей унаслідок вичерпання природних ресурсів і деградації навколишнього природного середовища $[8,11]$.

Реалізація проекту впровадження СЕМ пов'язана 3 перерозподілом обов'язків у загальній системі управління організацією. У зв'язку з цим можливе виникнення організаційних ризиків, які пов'язані $з$ помилками в роботі менеджера проекту або членів команди проекту та 3 внутрішнім опором організаційним змінам. Також у такому проекті важче, ніж в інших типах проектів, визначити кількісно i якісно результати, тому що вони пов'язані, як правило, з організаційним поліпшенням системи.

Висока вірогідність виникнення політичних ризиків $\epsilon$ ще однією особливістю вищезазначених проектів. Такі ризики можуть бути проявлені у змінах керівництва місцевої адміністрації та змінах складу депутатського корпусу, що може призвести до зміни стратегічних напрямів розвитку організації в цілому. Також у процесі реалізації проектів впровадження CEM на рівні муніципальних утворень можуть бути задіяні різні суспільні групи, які проявляють потенційну зацікавленість діяльністю органів місцевого самоврядування або комунальних підприємств, тому слід проводити всебічний аналіз та ідентифікацію пов'язаних з ними зовнішніх ризиків.

Необхідною умовою проекту впровадження СЕМ $€$ врахування місцевих природних, соціальних та економічних особливостей території муніципального утворення в межах конкретних об'єктів та середовища, що їх оточує. Також на стадії розробки проекту важливим моментом $є$ той аспект, що ліквідація прямих або опосередкованих наслідків негативного впливу на довкілля коштує набагато 
дорожче, ніж проведення превентивних заходів 3 охорони навколишнього середовища.

Процес реалізації проектів впровадження СЕМ супроводжується створенням нової організаційної структури, враховуючи при цьому як зміни внутрішніх факторів, так і розвиток зовнішнього середовища організації. Для створення ефективної структури управління визначається таке співвідношення іï організаційних елементів, при якому найбільш оперативно і своєчасно виконуються вимоги об'єкта управління при забезпеченні широкої взаємодії із зовнішнім середовищем.

Також як особливості управління проектом впровадження СЕМ можна відзначити застосування методів превентивного управління, які грунтуються на проведенні заходів щодо ідентифікації, оцінювання та управління ризиками в процесі реалізації проекту. Додаткове проведення якісного моніторингу ризиків забезпечує управління інформацією, яка допомагає приймати ефективні рішення до настання ризикових подій. Окремо відзначимо необхідність застосування методів подолання опору змінам в організації.

Крім того, обов'язковими складовими процесу управління таким проектом є управління витратами і збереженням ресурсів, їх раціональний вибір i транспортування та управління витратами енергії, вибір джерел енергозабезпечення, енергозбереження.

Процеси управління змінами стану довкілля включаються до всіх стадій життєвого циклу проекту, а вплив на стан довкілля враховується для всіх предметних груп управління проектом $[8,9]$. При виборі управлінських дій слід керуватися їх екологоекономічною ефективністю та вимогами стандарту в сфері екологічного менеджменту ISO 14000. Також слід зауважити, що ефективна реалізація проектів впровадження CEM вимагає наявності різноманітних форм активної роботи із зацікавленими сторонами, таких як: визначення їх основних ключових проблем, точок зіткнення інтересів, обмежень i можливостей, вивчення наявних матеріалів, проведення додаткових досліджень, контактів і обговорень із зацікавленими сторонами.

Таким чином, на рівні муніципального утворення метою такого проекту може виступати впровадження CEM у діяльність комунального підприємства або окремого підрозділу місцевої адміністрації та сертифікація
СЕМ відповідного підприємства (підрозділу) згідно з вимогами стандарту ISO 14000.

Реалізація встановленої мети проекту потребує виконання наступних завдань:

1. Розробити екологічну політику підприємства (підрозділу).

2. Провести ідентифікацію та оцінку значних екологічних впливів підприємства (підрозділу).

3. Розробити програму впровадження CEM.

4. Провести навчання працівників підприємства (підрозділу).

5. Мінімізувати опір організаційним змінам на підприємстві (в підрозділі). ризики.

6. Мінімізувати зовнішні i внутрішні

7. Провести екологічний аудит.

8. Провести аналіз СЕМ керівництвом підприємства. льні дії.

9. Розробити та впровадити коригува-

Висновки. В сучасних умовах реалізація проекту впровадження СЕМ на рівні муніципального утворення дозволяє створити якісну місцеву систему управління екологічною діяльністю при одночасному зменшенні негативного впливу на довкілля та економії природних ресурсів. Визначено мету, основні завдання та кваліфікаційні характеристики проекту впровадження СЕМ. До основних зацікавлених сторін такого проекту належать керівництво та співробітники місцевої адміністрації, місцеве населення, громадські організації, органи управління в екологічній сфері.

Серед особливостей управління проектами впровадження СЕМ можна виділити застосування методів превентивного управління, обов'язкове включення до проекту методів управління витратами ресурсів і енергії та врахування процесів управління змінами стану довкілля на всіх стадіях життєвого циклу.

Також основними ризиками реалізації такого проекту є організаційні ризики, політичні ризики, ризики, пов'язані з суспільними групами, та опір організаційним змінам, тому одним із ключових моментів успіху реалізації проекту впровадження СЕМ є робота із зацікавленими сторонами.

\section{Список літератури}

1. Астафьева О. В., Дерягина С. Е. Внедрение системы экологического менеджмента 
в органах местного самоуправления. Лидерство и менеджмент. 2018. № 4. Т. 5. URL: https://creativeconomy.ru/lib/39515 (дата звернення: 02.10.2018).

2. Гавадзин Н. О. Аспекти управління реалізацією екологічних проектів. Науковий вісник Ужгородського університету. Серія: Економіка. Ужгород, 2015. Вип. 1 (1). С. 110-112.

3. Мартиненко В. О. Екологічний менеджмент як нова парадигма муніципального управління. Теорія та практика державного управління: зб. наук. праць ХарРІ НАДУ при Президентові України. Харків, 2009. № 2 (25). С. 116-120.

4. Олексієнко М. М. Проактивний підхід до управління екологічними проектами. Управління розвитком складних систем: зб. наук. праць КНУБА. 2013. № 14. URL: http://journals.uran.ua/urss/article/view/4099 1/37313 (дата звернення: 16.08.2018).

5. Руденко С. В. К вопросу оценки результатов природоохранного проекта на основе принципов ценностного подхода. Проблеми техніки: наук.-вироб. журн. Одеса, 2010. № 4. С. 48-59.

6. Смоленніков Д. О. Роль стейкхолдерів у запровадженні екологічної відповідальності підприємств. Вісник СумДУ. Серія: Економіка. Суми, 2015. № 4. С. 12-16.

7. ДСТУ ISO $14001: 2006$. Системи екологічного управління. [Чинний $з$ 2006-0515]. Київ, 2006. 7 с. (Вимоги і керівництво $з$ використання).

8. Хрутьба В. О. Креативна модель проекту впровадження системи екологічного менеджменту транспортного підприємства. Східно-Свропейський журнал передових технологій. 2013. № 1/10 (61). URL: https://elibrary.ru/item.asp?id=19067361 (дата звернення: 15.07.2018).

9. Panya N. et al. The performance of the environmental management of local governments in Thailand. Kasetsart Journal of Social Sciences. 2018. No. 39. P. 33-41. URL: https://reader.elsevier.com/reader/sd/5EF49 1FB30456BC9F327ED101A9EA1A942220 CBF2EECF9390115006DA339A7001EDC 44899BFC8505E3F50E051940404C (Last accessed: 25.10.2018).

10. Reed M. S. Stakeholder participation for environmental management: A literature review. Biological conversation. 2008. № 141. URL: https://pdfs.semanticscholar.org/384f/a0881 8e5b561453a2f86ce521ff8fc12c9b1.pdf (Last accessed: 21.10.2018).

11. Устойчивое развитие предприятия, региона, общества: инновационные подходы к обеспечению: монография / под общ. ред. О.В.Прокопенко. Польща: Drukarnia i Studio Graficzne Omnidium, 2014. $474 \mathrm{c}$.

\section{References}

1. Astafyeva, O. V., Deriahyna, S. E. (2018) Implementation of the system of ecological management in local government bodies. Liderstvo $i$ menedzhment, No. 4, vol. 5. URL: https://creativeconomy.ru/lib/39515 (Last accessed: 02.10.2018) [in Russian].

2. Havadzyn, N. O. (2015) Aspects of management by the implementation of environmental projects. Naukovyi visnyk Uzhhorodskoho universytetu. Seriia: Ekonomi$k a$. Uzhhorod, iss. 1 (1), pp. 110-112 [in Ukrainian].

3. Martynenko, V. O. (2009) Ecological management as a new paradigm of municipal governance. Teoriia ta praktyka derzhavnoho upravlinnia: coll. of sci. works of KharRI NAGM under the President of Ukraine. Kharkiv, No. 2 (25), pp. 116-120 [in Ukrainian].

4. Oleksiienko, M. M. (2013) Proactive approach to managing environmental projects. Upravlinnia rozvytkom skladnykh system: coll. of sci. works of KNUBA, No. 14. URL: http://journals.uran.ua/urss/article/view/409 91/37313 (Last accessed: 16.08.2018) [in Ukrainian].

5. Rudenko, S. V. (2010) On the issue of assessing the results of the environmental project based on the principles of value approach. Problemy tekhniky: sci. and production journ. Odesa, No. 4. pp. 48-59 [in Russian].

6. Smolennikov, D. O. (2015) The role of stakeholders in the implementation of environmental responsibility of enterprises. Visnyk SumDU. Seriia: Ekonomika. Sumy, No. 4, pp. 12-16 [in Ukrainian].

7. DSTU ISO 14001:2006. Environmental management systems. [Effective from 200605-15]. Kyiv, 7 p. (Requirements and usage guidelines) [in Ukrainian].

8. Khrutba, V. O. (2013) Creative model of the implementation project of the environmental 
management system of the transport enterprise. Skhidno-Yevropeiskyi zhurnal peredovykh tekhnolohii, No. 1/10 (61). URL: https://elibrary.ru/item.asp?id=19067361 (Last accessed: 15.07.2018) [in Ukrainian].

9. Panya, N. et al. (2018) The performance of the environmental management of local governments in Thailand. Kasetsart Journal of Social Sciences, No. 39, pp. 33-41. URL: https://reader.elsevier.com/reader/sd/5EF49 1FB30456BC9F327ED101A9EA1A942220 CBF2EECF9390115006DA339A7001EDC
44899BFC8505E3F50E051940404C (Last accessed: 25.10.2018).

10. Reed, M. S. (2008) Stakeholder participation for environmental management: A literature review. Biological conversation, No. 141. URL: https://pdfs.semanticscholar.org/384f/ a08818e5b561453a2f86ce521ff8fc12c9b1.p df (Last accessed: 21.10.2018).

11. Prokopenko, O. V. (ed.) (2014) Sustainable development of an enterprise, region, society: innovative approaches to provision: monograph. Poland: Drukarnia i Studio Graficzne Omnidium, 474 p. [in Russian].

\author{
N. V. Gurets, senior lecturer \\ of the Ecology and Environmental Technologies Department \\ Admiral Makarov National University of Shipbuilding \\ Heroes of Ukraine ave., 9, Mykolaiv, Ukraine \\ e-mail: natalya.gurets@nuos.edu.ua
}

\title{
PROJECT MANAGEMENT OF IMPLEMENTATION OF ENVIRONMENTAL MANAGEMENT SYSTEM IN MUNICIPAL INSTITUTIONS
}

Environment sharp deterioration on municipalities' territory as a result of increased production capacity of new productions and aggravation of their impact on nature; the population growth and the increase in hazardous waste production volume, the rise of the vehicles number causes the need for the implementation of environmental management system in municipal management. The process of environmental management system creating and implementing in the municipal administration involves the development of environmental policy, taking into account the interests of all stakeholders; assessment of the current situation; establishing performance characteristics to be improved; development of ecological program; practical implementation of the planned activity; monitoring, corrective action, analysis and audit.

The purpose of the article is to determine the aim, tasks and main classification characteristics of the environmental management system implementation project, coverage of key stakeholders and management features of such a project. The essence of the project of implementation of environmental management system is described, its classification is determined, the project constraints and possible risks are identified. The aim and main objectives of the project are formulated.

Analysis of the environmental management system implementation project stakeholders in municipality play an important role for the success of the project, therefore the article outlines the main stakeholders of the project and the risks associated with them. The identified features of project management of implementation of environmental management system point to the need for the use of preventive management in the process of its implementation, mandatory inclusion in the project of the methods of work with stakeholders and taking into account the processes of managing by environmental changes at all stages of the life cycle.

Keywords: ecological management system, project of implementation of ecological management system, organizational project, project stakeholders. 